\title{
The Effectiveness of Physical Education Learning in Elementary School Located in Wetland Environment
}

\author{
Mashud
Department of Physical Education and Health \\ Mashud
Department of Physical Education and Health \\ Faculty of Teachers Training and Edication Lambung Mangkurat University
}

\begin{abstract}
INFO ARTIKEL
Riwayat Artikel:

Diterima: 10-12-2019

Disetujui: 20-02-2020

Kata kunci:
effectiveness;
physical education;
wetland;
keefektifan;
pendidikan jasmani;
lahan basah

Abstract: This paper aims at finding out the effectiveness of Physical education subject in elementary school in wetland areas. This paper used qualitative and quantitative descriptive research. This paper took the entire schools in wetland areas (around Banjar and Baritokuala Regency) as the population. The sample of this research was taken by using a purposive sampling method. This paper used the assessment instrument of the teacher's ability, which focuses on the learning stage (Pre-, during, and Post-) and interview guidelines. The data obtained were analyzed using quantitative and qualitative descriptive analysis. The results found that the Physical education subject of elementary school is ineffective. This paper found several points as contributing factors, they are: (1) environmental factors, (2) school management factor, (3) teacher factors, and (4) customary factors.
\end{abstract}

lahan basah

ABSTRAK

\begin{abstract}
Abstrak: Makalah ini bertujuan untuk mengetahui efektivitas mata pelajaran pendidikan jasmani di sekolah dasar di daerah lahan basah. Makalah ini menggunakan penelitian deskriptif kualitatif dan kuantitatif. Populasi penelitian ini adalah seluruh sekolah di daerah lahan basah (sekitar Banjar dan Kabupaten Baritokuala). Sampel penelitian ini diambil dengan menggunakan metode purposive sampling. Penelitian ini menggunakan instrumen penilaian kemampuan guru, yang berfokus pada tahap pembelajaran (Pra-, selama, dan pasca-) dan pedoman wawancara. Data yang diperoleh dianalisis menggunakan analisis deskriptif kuantitatif dan kualitatif. Hasil penelitian menemukan bahwa mata pelajaran pendidikan jasmani sekolah dasar tidak efektif. Penelitian ini menemukan beberapa poin sebagai faktor yang berkontribusi, yaitu (1) faktor lingkungan, (2) faktor manajemen sekolah, (3) faktor guru, dan (4) faktor adat istiadat.
\end{abstract}

\author{
Alamat Korespondensi: \\ Mashud \\ Department of Physical Education and Health \\ Faculty of Teachers Training and Edication Lambung Mangkurat University \\ E-mail: mashud@ulm.ac.id
}

Learning effectiveness performed by teachers significantly determines the achievement of Physical education, Sport, and Health learning. Productive learning activity does not only rely on the final score of student's learning outcome, but it also should consider several supporting elements such as learning achievement indicators, learning objectives, learning competency, learning strategies and methods, learning assessment, and follow-up on learning evaluation. In addition to the six elements above, structured, appropriate, and systematic learning documentation also needs to be taken into account as the vital element.

Learning activities should encourage active participation, creating challenging atmosphere but remain considering student's development stage, pay attention to the message delivered through the learning instruction, encourage independent learning of students in accordance with learning objectives. Suherman (2011), Jeschke et al. (2019), and Peterson et al. (2018) explained that the teacher should provide optimal learning opportunities for students. The teacher should not waste their time only teach students how to achieve particular learning competence and neglect other academic purposes. In addition, the teacher describes realistic expectations and rules of learning, classroom management and student engagement, meaningful learning assignments, and high levels of success. The teacher should present learning material proficiently and using the proper delivery approach. The teacher also should be active, responsible, transparent, enthusiastic, and warm in teaching and monitoring the learning process.

Specifically, Suherman (2011) and Astuti (2019) argues that the effectiveness of Physical Education, Sport, and Health learning can be measured based on several indicators. The leading indicator that is often used in measuring Physical Education, Sport and Health is the amount of study time and opportunity for students to learn the subject (Lope set al., 2017). Based on the above theoretical studies, this study took learning allocation time (time of study/brainstorming) in Physical Education, Sport, and Health lesson as a research instrument. The researcher also employed the description of teacher activity assessment tool in Physical Education, Sport, and Health lesson. 
The ideal learning effectiveness of Physical education, as described above, has not been achieved as expected. Numerous issues on the low quantity and quality of Physical, Sport, and Health education become the major concern recently (Li et al., 2019 \& Ding et al., 2018). A research conducted by Sulistiona (2014). which was carried out in a cross-sectional method in Bandung City and Majalengka Regency, with a total sample of 721 students taken by purposive cluster sampling found that $42.27 \%$ of elementary school students, $36.87 \%$ of junior high school students, and $46.11 \%$ high school students obtained low level of Physical fitness level. The results assume the low learning effectiveness, innovation and creativity of Physical Education, Sport, and Health teachers in teaching. It can be said that students do not accept the adequacy of movement in each learning. In addition, students do not receive sufficient and interesting mobile assignments that can be used as good experiences to be practiced outside the school hours.

Another specific research was research conducted by Pambudi, Winarno, \& Dwiyogo (2019) which examined the effectiveness of the implementation of lesson plan in Senior High School in Lumajang Regency. Overall, the implementation of learning in Senior High School in Lumajang consisted of (1) 45 minutes effective learning time allocation, (2) the nine minutes of preliminary activities, (3) approximately 44 minutes of primary activities, and (4) five minutes of closing activities. Based on the 2013 curriculum, it is explained that the allocation time of Physical Education, Sport, and Health lesson for high school is three hours in which one hour lesson is 45 minutes, so the total time allocation is 135 minutes in one meeting. From the results of the study above, it shows that the level of effectiveness of Physical Education, Sport, and Health learning in Lumajang Regency High School was deficient.

In addition, a study by Kusuma and Winarno (2018) about the time effectiveness of Physical Education, Sport, and Health learning in Junior High School in Malang reported that the teachers used 18 minutes for an average time of preliminary activities, 65 minutes for main activities, and 65 minutes also for closing activities. The findings indicated that the teacher used too much time in preliminary activities and closing activities. Thus, it can be concluded that the time allocation for main activities is still less effective. It is assumed that the learning was counterproductive. Physical Education, Sport, and Health is an important part of the whole education process with the aim of improving human performance through physical activity to develop and maintain the human body (Mashud, 2015). Physical Education, Sport, and Health is an important and mandatory subject that must be taught in school. Physical Education, Sport, and Health subject intend to maintain the physical fitness of students. In addition, Physical Education, Sport, and Health subject are inseparable from qualified and professional teachers (Mashud, 2018).

Based on some of the research results above, it can be concluded that there are still many lacks and gaps between expectations and reality. Therefore, Physical Education, Sport, and Health learning still need to be paid attention in terms of its implementation, which includes teachers' competency, headmaster's competency, and school supervisor's competency. There are many supervising processes through a form of research on the quality of Physical Education, Sport, and Health subject in several regions of Indonesia. For instance, in the Java Island region, like some of the above research findings, the learning is continuously and sustainably often implemented. However, the findings above have not yet been found in another region, such as in South Kalimantan, which is characterized as a wetland region.

Scientific studies of educational settings in the wetlands region such as Natural Sciences, Social Sciences, and Languages are commonly developing. However, it has not been found any scientific studies in the field of Physical Education, Sport, and Health subject. For instance, a study conducted by Aini, Zainudin, and Mahardika (2018) examined the development of Natural Science instructional materials using a cooperative learning model that is oriented to the wetland environment. Similarly, Ihksan, Jamal, and Salam (2017) studied the development of environmentally oriented learning instruments around the banks of the Barito River to train science process skills. In addition, Khairunnisa and Salamah (2018) examined the development of the wetland environmental education learning model in Madrasah Ibtida'iyah (Islamic elementary school). Those three research profiles illustrate that the scientific study about Physical Education, Sport, and Health learning of school in the wetland environment has not been conducted.

Based on the above research findings, this study aims to reveal the effectiveness of Physical Education, Sport, and Health learning in schools located in the wetland region. This research focuses on the effectiveness of the allocation time in Physical Education, Sport, and Health learning for elementary school students. It is expected that the results of this study will be able to explain various Physical Education, Sport, and Health learning problems in schools in the wetland region both in terms of learning management, learning processes, learning assessment, environmental studies and infrastructure, social-cultural studies and regional education policy studies.

\section{METHOD}

The research method used was a qualitative-quantitative descriptive method. By combining these two methods, the researcher aimed to obtain more accurate and complimentary research results. The population in this study was all elementary schools in Cintapuri Darussalam District, Banjar Regency, and all elementary schools in Anjir Muara District, Barito Kuala Regency. The sample of this study was headmaster and Physical Education, Sport, and Health subject teacher of elementary schools in the wetland region. Schools taken in Cintapuri Darussalam District are; (1) SDN Galam Rabah, (2); SDN Galam Rabah 2; (3) SDN Galam Rabah 3; (4) SDN Simpang Lima. While the schools taken in Anjir Muara District are (1) SDN Anjir Muara Kota 1; (2) SDN Marabahan 1; (3) SDN Anjir Muara Lama. The samples were taken by using a purposeful sampling technique. 
The study was conducted from October to December 2019. Quantitative data analysis was used descriptive statistical percentages, while the analysis of qualitative data employed the stages of data collection, data reduction, data display, and drawing conclusions.

\section{RESULTS AND DISCUSSION}

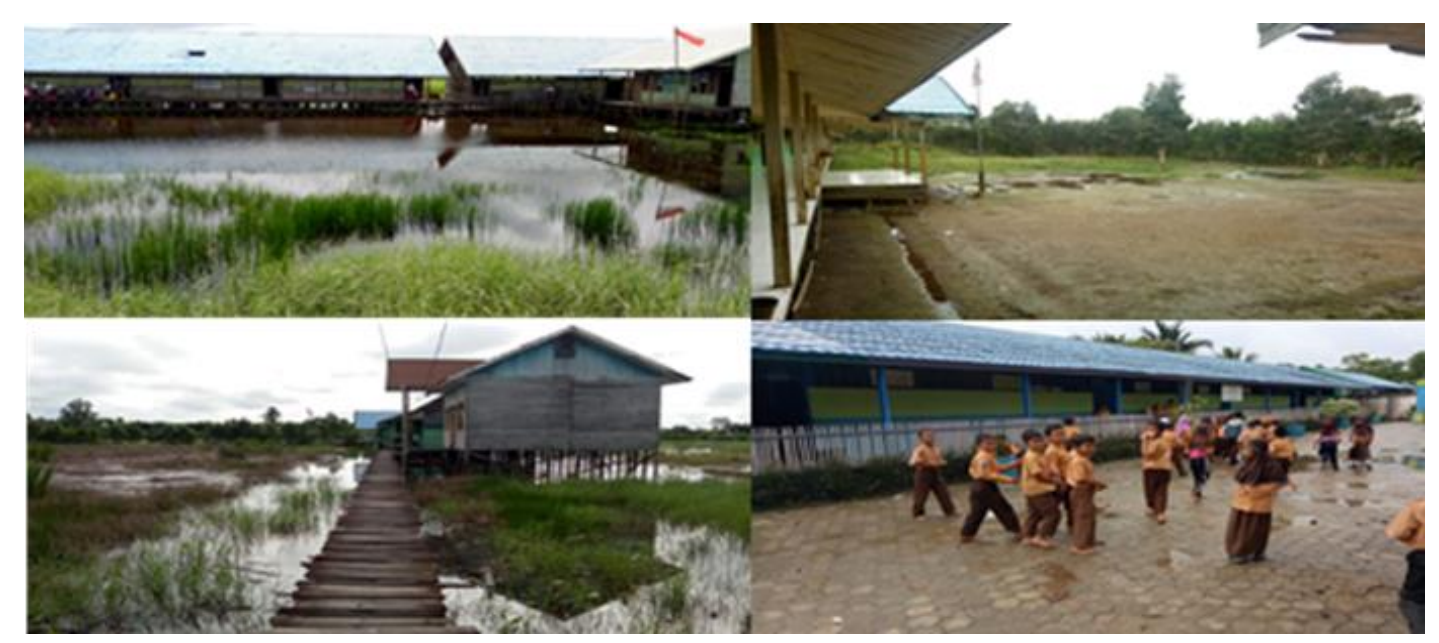

Figure 1. Profiles of Some Elementary Schools in Wetland Region of the South Kalimantan Province

The results of interviews and observations of the headmasters and Physical Education, Sport, and Health teachers are broadly divided into two parts (1) the area is wet because the location of the school is in the peat and swamp area and (2) the area is wet because the location of the school is on the riverbank. The schoolyard in peat and swamp areas during the rainy season is submerged in water from December to April. During the dry season, the schoolyard is dry, dusty, and prone to irritate the eyes and breathing. Whereas the elementary schools located on the riverbanks, the land was dry in the dry season. It will be wet and muddy and even submerged due to overflowing river water and the classroom. It will be inundated when it is a rainy season between December and April. The submergence of the school around the riverbank can happen at any time, due to the river overflowed. During the rainy season, teaching and learning activities in schools are interrupted, and sometimes, it is even being canceled. All teachers and students need to work together to clean the yard and classroom. Thus, it has a profound impact on the learning process, especially Physical Education, Sport, and Health learning that requires schoolyard or field. The school principal and teachers can do nothing to avoid the situation. There have been several requests to the Education Department of the Regency and the Village Government and also donors or companies in the surrounding area regarding the procurement of land for reclamation or field procurement from wooden boards that can stand on water. However, until now, all those efforts have not worked. Therefore, the learning process is just left as it usually goes. The following Table 1 indicates the quantitative data on the time allocation spending for Physical Education.

Table. 1. Time Allocation for Physical Education

\begin{tabular}{rrrrcc}
\hline \multirow{2}{*}{ No } & \multirow{2}{*}{ Teacher } & \multirow{2}{*}{ Class } & \multicolumn{3}{c}{ Observation Results } \\
\cline { 4 - 6 } & & Total Time & Learning Time & Percentage \\
\hline 1 & Teacher 1 & IV & 140 minutes & 0 minutes & $0 \%$ \\
2 & Teacher 2 & IV & 140 minutes & 0 minutes & $0 \%$ \\
3 & Teacher 3 & III & 140 minutes & 60 minutes & $42.8 \%$ \\
4 & Teacher 4 & III & 140 minutes & 65 minutes & $46.4 \%$ \\
5 & Teacher 5 & III & 140 minutes & 65 minutes & $46.4 \%$ \\
6 & Teacher 6 & V & 140 minutes & 75 minutes & $53.5 \%$ \\
7 & Teacher 7 & V & 140 minutes & 59 minutes & $42.1 \%$ \\
\hline \multicolumn{4}{r}{ Total } & 324 minutes & $230.6 \%$ \\
& & & Average & 46.28 minutes & $33.05 \%$ \\
\hline
\end{tabular}

From the table above, it can be said that the effectiveness level of Physical Education, Sport, and Health learning is very low. It is seen from the allocation time spending for Physical Education, Sport, and Health learning. The total allocation time was only $33.05 \%$ of the learning time provided. Based on the curriculum, the time allocation for Physical education should reach 140 Minutes (4 X 35 minutes) each face-to-face meeting in a week. The findings reveal that $66.95 \%$ of the time was wasted. Physical Education, Sport, and Health learning are effective if the amount of time spent in learning is getting higher, and students are actively moving to carry out the assignments given by the teacher. 
The quantitative findings above are strengthened by qualitative data collected by the researcher from the respondents. The results inform some factors of the ineffective learning process in schools located in the wetland area. These factors include (1) A frequently wet area in school inhibits learning activities. In addition, when the schoolyard is wet, it dangerous to do outdoor activities. Thus, when the schoolyard is wet, outdoor learning for Physical education is not conducted; (2) After the overflowed river occurring, the school is full of dirt, such as mud and other rubbish. The school members need to clean up the environment, and it takes time, which inhibits the learning process. If it is not immediately taken care of, sooner or later, it will impact student's health; (3) Alternative places for learning are not available to be used. When a school uses other alternative places such as mosque yard or surrounding people's house yard, it also creates an ineffective learning process due to inevitable disturbance. Thus, the teacher is less able to carry out optimal and maximal learning activities. Besides, to reach alternative places takes extra travel time and requires extra supervision to the students. Such conditions will certainly greatly affect the learning process and the achievement of Physical Education, Sport, and Health learning objectives. Hanggara, Soegiyanto, \& Sulaiman (2019) explained that for the ideal implementation of Physical Education, Sport, and Health learning, schools must have open space of at least three square meters per one student; (4) Another alternative place to carry out Physical Education, Sport, and Health learning is a relatively empty room, usually, a library when the school is flooded. However, the teacher is not accustomed to teaching in the narrow area, and commonly teachers design the learning activities based on a representative field. Thus the learning becomes less effective. The learning was running, but the goal was definitely not maximally achieved; (5) Customary habits that occur in the community also influence the learning process. This factor is very influential in the school activities, not only on one subject but also on the whole school program. For example, the custom of harvesting, during the harvesting season, the student does not go to school. In addition, when there are other ceremonial events, neither marriage nor burial of the death, the students do not go to school because they need to be involved in the ceremonies.

Some of the reasons above have caused an ineffective learning process, particularly when dealing with overflowed water in the school areas. Some school principals have proposed to solve the issues. However, up to now, no significant attempt was made to improve the condition. Unfortunately, when dealing with ceremonial events, the schools have not found any possible attempt to solve. Some school principals have discussed and consolidated with the parents and the village apparatus. However, it unsuccessfully changed the condition. Primitive and old-fashioned thinking is still very closely attached to the wetland environment. The majority of wetland environment schools are located in rural areas. The status of school accreditation is in the majority of $\mathrm{C}$ accreditations, and some are not even accredited.

The above-mentioned explanation indicates that the issues are crucial for the effectiveness of the learning process, particularly for Physical education, Sport, and Health subject. The success of Physical education relies on the active movement carried out by the students (Koryahin \& Blavt, 2018; Valianto, 2019). If the students are not actively involved, it is assumed that the learning is not successfully conducted. In addition, if students passively involved in the movement carried out during Physical education, it influences student's physical fitness (Mashud, 2016). Numerous factors affect the issues above, such as environmental factors and school management. In terms of school management, when the school principal neglects some environmental issues which inhibit the learning process or if they have insignificant ideas to solve the issues, the learning process will remain ineffective (Kharisma \& Istiningsih, 2017). The teacher of Physical education can also contribute to the ineffective learning process.

Flood in the school areas annually occurs. Therefore, the teacher should have better preparation. The teacher should be able to modify the learning activities in accordance with the situation of the school environment (Obiechina, 2018). For example, the teacher could design alternative learning activities that do not require a large field. For instance, learning cardiorespiratory resistance does not have to run far around the field but can be replaced by going up and down the bench, running in place, modifying the game by utilizing the school terrace or classroom, etc. Furthermore, to solve the issues, it requires good coordination and cooperation. The school principal cannot work alone without cooperation with the related parties. As well as teachers, they cannot dependently solve the issues by relied on the strategies they employ.

In addition to the solutions offered above, the school principal function in carrying out entrepreneurship competencies also plays an important role in overcoming the problem, specifically the problem of learning effectiveness in terms of the duration of the Physical Education, Sport, and Health learning activities. Entrepreneurship of school principals to respond immediately and analyze the causes of the problem is vital. As an education unit official with a superior position, the school principal is able to submit a proposal to the regional education office. The solution proposed could be in the form of material fulfillment for backfilling, or the making of ironwood pages or others. In addition to submitting proposals, another step is to have discussions and deliberations with the Village Head or government officials.

Village officials also should take part in solving the issues since the officials know betters the condition of the environment around schools. Moreover, the school is a village partner in the development of human resources in the village. Sometimes, the school building can be used for village events. Thus, if there are good coordination and cooperation, then all the problems that occur will be possible to immediately obtain a solution. The school principal must also be responsive to the environment around the school. School principal could ask for a CSR funding assistance from the surrounding multinational companies. 


\section{CONCLUSION}

Based on the results of the study, the learning process of Physical education, Sport, and Health subject in wetland areas is very low. It is indicated by the insufficient time allocation achieved in the schools. In addition, based on the interviews with the school principal and the teachers, the issues that occur in the schools are: (1) inevitable environmental factors such as the characteristics of the areas (swamp areas and riverbank areas); (2) the school principal management in managing the school; (3) Physical education, Sport, and Health subject teachers who pay less attention to design alternative learning innovation which in accordance with the characteristics of school areas; (4) cultural tradition among society which could not be separated from their daily life.

Based on the conclusion explained above, it is expected for the school principal to improve the leadership ability, particularly in managing the school to provide a better response when the problems around the school occur. The ability of school management is important to provide a good solution to school-related issues. Then, for Physical education, Sport, and Health teachers, it is suggested to be creative in designing the alternative learning approaches based on the school and student characteristics. Last but not least, for the future researchers, it is suggested to carry further examination to identify and analyze the learning management, learning process, learning evaluation, social-cultural background of the school, as well as the educational policy stipulated by the local government.

\section{REFERENCES}

Aini, N., Zainudin., \& Mahardika, A. I. (2018). Pengembangan Materi Ajar IPA Menggunakan Model Pembelajaran Kooperatif Berorientasi Lingkungan Lahan. Berkala Ilmiah Pendidikan Fisika, 6(2), 264-277. https://doi.org/10.20527/bipf.v6i2.4919

Hanggara, A. S. D., Soegiyanto, \& Sulaiman. (2019). Learning Infrastructure Facilities for Physical Education, Sports, and Health Public Elementary Schools. Journal of Physical Education and Sports, 8(1), 26-32. https://doi.org/doi.org/10.15294 /jpes.v8i1.26295

Ihksan, I. N., Jamal, M. A., \& Salam, A. (2017). Pengembangan Perangkat Pembelajaran Berorientasi Lingkungan Sekitar Bantaran Sungai Barito untuk Melatihkan Keterampilan Proses Sains. Berkala Ilmiah Pendidikan Fisika, 5(1), $29-45$.

Khairunnisa, \& Salamah. (2018). Pengembangan Model Pembelajaran Pendidikan Lingkungan dengan Lahan Basah pada Madrasah Ibtida'iyah. EDUSAINS, 10(1), 22-30. https://doi.org/http://dx.doi.org/10.15408/es.v10i1.7217

Kusuma, R. A., \& Winarno, M. (2018). Efektivitas Waktu Pembelajaran PJOK Di Sekolah Menengah Pertama. Gelanggang Pendidikan Jasmani Indonesia, 2(2), 135-141.

Mashud, M. (2015). Pendekatan Pembelajaran Pendidikan Jasmani Olahraga dan Kesehatan di Era Abad 21. Jurnal Multilateral, 14(2), 89-196.

Mashud, M. (2016). Model Sekolah Berwawasan Kebugaran Jasmani. Multilateral Jurnal Pendidikan Jasmani dan Olahraga, 15(1), 75-86. https://doi.org/10.20527/multilateral.v15i1.2485

Mashud, M. (2018). Analisis Masalah Guru PJOK Dalam Mewujudkan Tujuan Kebugaran Jasmani. Multilateral Jurnal Pendidikan Jasmani Olahraga, 17(2), 77-85.

Pambudi, M. I., Winarno, M., \& Dwiyogo, W. D. (2019). Perencanaan dan Pelaksanaan Pembelajaran Pendidikan Jasmani Olahraga Kesehatan. Jurnal Pendidikan: Teori, Penelitian, dan Pengembangan, 4(1), 110-116.

Sulistiona, A. A. (2014). Kebugaran Jasmani Pendidikan dasar dan Menengah di Jawa Barat. Jurnal Pendidikan dan Kebudayaan, 20(2), 223-233.

Suherman, Adang. (2011). Realitas Kurikulum Pendidikan Jasmani: Upaya Menuju Kurikulum Berbasis Penelitian. Bandung: Rizqi Press.

Jeschke, C., Kuhn, C., Lindmeier, A., Zlatkin-Troitschanskaia, O., Saas, H., \& Heinze, A. (2019). Performance Assessment to Investigate the Domain Specificity of Instructional Skills among Pre - Service and In - Service Teachers of Mathematics and Economics. British Journal of Educational Psychology, 89(3), 538 - 550.

Peterson, C. A., Dooley, L. J., \& Fan, L. (2018). Home Visiting Programs. YC Young Children, 73(4), 36-41.

Astuti, Y., \& Kumar, A. (2019). Motoric Ability and Nutrition Status Factor Analysis with the Learning Outcomes Playing Skill of Volley Ball. KnE Social Sciences, 689-704.

Lopes, V. P., Stodden, D. F., \& Rodrigues, L. P. (2017). Effectiveness of Physical Education to Promote Motor Competence in Primary School Children. Physical Education and Sport Pedagogy, 22(6), 589-602.

Li, J. (2019, January). Research on College Physical Education Reform Based on the Demand for Happy Physical Education. In 3rd International Seminar on Education Innovation and Economic Management (SEIEM 2018). Atlantis Press.

Ding, X., Hong, P., Zhang, R., \& Zhang, Y. (2018). Research on the Primary and Middle School Students' Sports Development in Jiangsu and its Influencing Factors. Chinese Journal of School Health, (2), 20.

Koryahin, V., \& Blavt, O. (2018). The Use of Information and Communication Technology for Determining the Level Mobility in Joint in Physical Education of Students. Teoriâ Ta Metodika Fìzičnogo Vihovannâ, 18(3), 107_-113.

Valianto, B. (2019). Effectiveness of Physical Fitness Model with Game Approach in Improving Physical Fitness of Students at Gajah Mada Elementary School in Medan. Journal of Physics: Conference Series, 1387(1). 
270 Jurnal Pendidikan, Vol. 5, No. 2, Bln Februari, Thn 2020, Hal 265-270

Kharisma, R. S., \& Istiningsih, I. (2017). Iptek bagi Masyarakat Taman Kanak-Kanak di Desa Kalitirto Kecamatan Berbah. JPP IPTEK (Jurnal Pengabdian dan Penerapan IPTEK), 1(1), 29-38.

Obiechina, F. N., Abraham, N. M., \& Nwogu, U. J. (2018). Perceived Impact of School Environmental Insecurity on Teachers' Productivity in Public Secondary Schools in Anambra State, Nigeria. International Journal of Innovative Social \& Science Education Research, 6(4), 43 - 48.

Harrison, C., Burnard, K., \& Paul, S. (2018). Entrepreneurial Leadership in a Developing Economy: A Skill-Based Analysis. Journal of Small Business and Enterprise Development, 25(3), 521-548. 